\title{
CORRESPONDENCE
}

\section{A. O. U. Luncheons}

Editor of 'The Auk':

One of the most pleasant features of our annual meetings is the lunch provided each day by the local committee as it gives those in attendance an opportunity for social intercourse which would otherwise be impossible. Many of our members have long felt the obligation we are under to the Delaware Valley Ornithological Club, the Nuttall Club, the Linnaean Society of New York, the Biological Society of Washington, and the members of various local committees who in the past have so cheerfully and silently contributed to the entertainment fund, but very few of us have fully understood, even with our own experience with the "high cost of living," how great a burden the more recent meetings have proved to the financial resources of our local committees.

The meeting of the American Society of Mammalogists in New York, last May, has shown that the lunch hour can be equally successful if the members pay for their own lunch and the feeling expressed on this point was one of general approval. Some of us, who from our geographical position cannot hope to return the hospitality of our fellow members, feel that on that account we are less embarrassed in suggesting that while the daily lunches be continued as heretofore that each one pay his own share as is already the custom in connection with our annual dinner.

Toronto, Ontario.

June 7, 1920.

\section{W. E. SaUnders,} J. H. Fleming.

[While we feel sure that the several local committees have been only too glad to entertain the visiting ornithologists at past A. O. U. meetings and are quite willing to continue to act as hosts at the luncheons, we realize that there is a more serious factor involved in this matter which directly affects the welfare of the Union. We must all realize that the influence of the Society would be greater if meetings could be held in a greater number of localities than is now customary, but the local expenses referred to by our correspondents, make it impossible to hold meetings away from the several centers of ornithological activity where there is a large resident membership. Increased attendance at the meetings which is especially desirable, tends further to aggrivate this condition. We therefore feel that Messrs. Saunders and Fleming in their courteous and thoughtful note have opened up the way to an important innovation which may prove a lasting benefit to the A. O. U. 


\section{$2 \mathrm{BHL}$ Biodiversity Heritage Library}

Saunders, William Edwin and Fleming, James H. 1920. "A. O. U. Luncheons." The Auk 37, 498-498. https://doi.org/10.2307/4073330.

View This Item Online: $\underline{\text { https://www.biodiversitylibrary.org/item/54106 }}$

DOI: https://doi.org/10.2307/4073330

Permalink: https://www.biodiversitylibrary.org/partpdf/86483

\section{Holding Institution}

Smithsonian Libraries

\section{Sponsored by}

Smithsonian

\section{Copyright \& Reuse}

Copyright Status: Public domain. The BHL considers that this work is no longer under copyright protection.

This document was created from content at the Biodiversity Heritage Library, the world's largest open access digital library for biodiversity literature and archives. Visit BHL at https://www.biodiversitylibrary.org. 